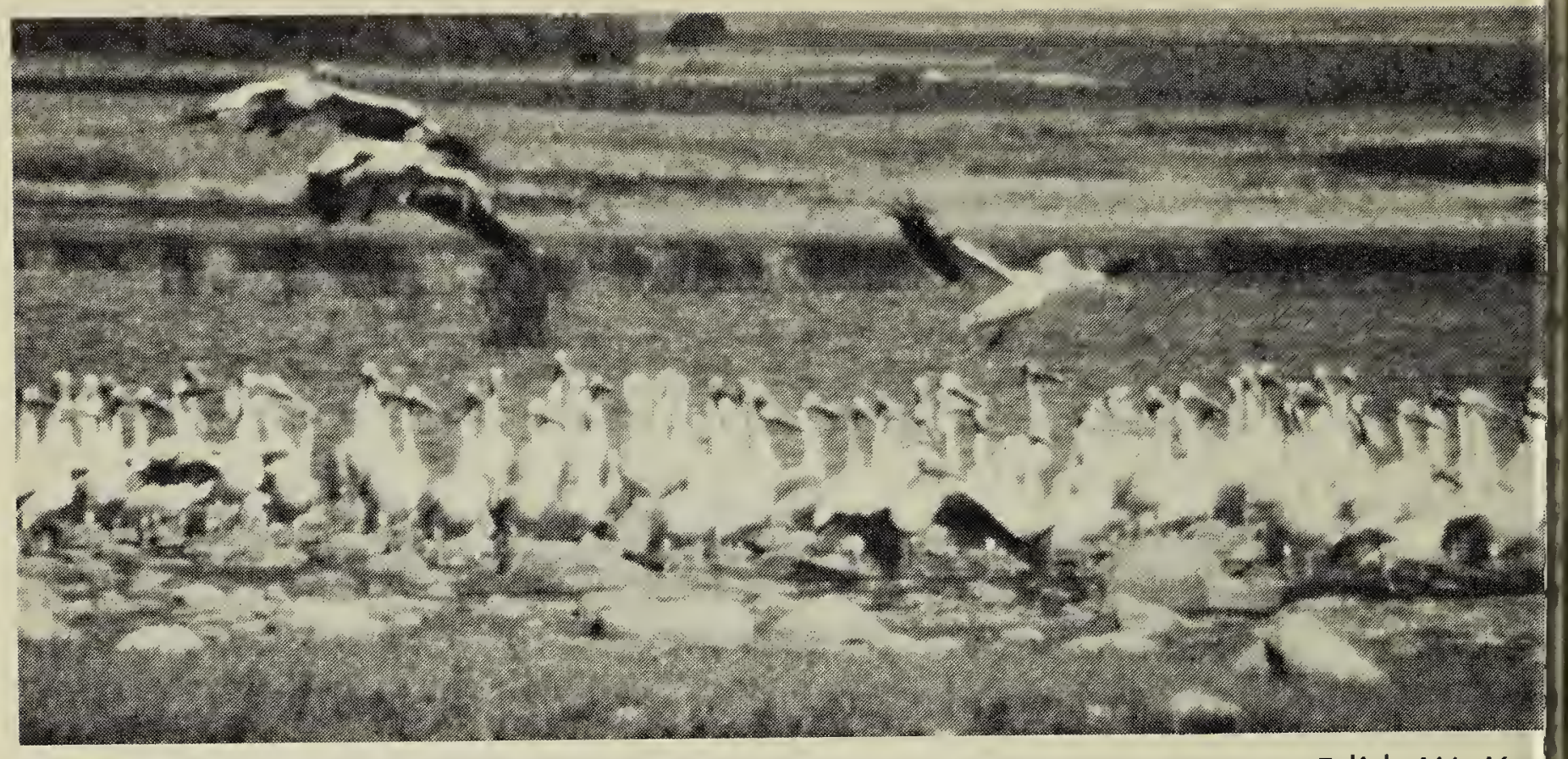

White Pelicans

Edith W. Ker

\section{PLENTY OF PELICANS}

On July 1, 1977, four members of the Moose Jaw Natural History Society (Molly Ritchie, Jean Thomson, Ruth Hilling, Edith Kern) drove to the west side of Pelican Lake (north from Mortlach) to the end of the old dam, and were astounded to see a "guestimated" $1500+$ White Pelicans! In the old days the Lake got its name from that noble bird. For many years, however, no White Pelicans were seen there. Then, about 6 or 7 years ago, the birds started to return, a few at a time, until the normal sightings were from 25 to 100 in a season. We talked to Del Duffy, who has farmed in that area for years, and he said he cannot recall ever seeing so many Pelicans at one time.

On July 15, Mickey Lane and I went back to check. We went in to the lake north of Besant Regional Park, as we didn't have time to go as far as last time, but you can see up to the dam from there, and we saw about 200-300 birds. Maybe we were lucky to see a peak movement ..... who knows? Edith W. Kern, 1086 Alder Ave., Moose Jaw, Saskatchewan S6H OY4.

\section{BIRDWATCHER'S PARTY}

To-day I had a birdwatcher's party, very unexpected! Wish I'd had some other birdwatcher to share it with me About noon my husband finishe irrigating his hay in the flat, south $c$ Val Marie. He came home and aske if I wanted to go and see som "orangy" birds that had flown in. took my bird book and field glass and away we went. The last strips be irrigated are next to the highw: so we stayed right on the road ar looked at around 150 birds; most gulls. The "orangy" birds turned o to be Yellow-headed Blackbirds.

There were about a dozen Yellov headed Blackbirds - male ar female - so it made me wonder were they not nesting yet? Or we they unmatched pairs and their mat on the nest?

One surprise I got were the gul All this time I had thought our $b$ common gull that follows the tract summerfallowing and shows up irrigation time was the Herring G but these I looked at were all Rin billed Gulls. There must have be nearly 100 of them.

The next most abundant was $t$ Franklin's Gull with its black hea There were quite a few of tho swooping down for food. The wat drives all the bugs and mice out of $t$ ground and these birds were havin hey-day! There must have been dozen Black Terns also diving doy for food. 
One beautiful Avocet strutted by imself, knowing he was the prettiest $f$ them all. Two couples of Marbled odwits were feeding in the shallow ater. These can't be nesting yet. If I ad seen any of them before I had ertainly never identified them. So it as a first for me.

That morning before we left I had en a Yellow Warbler in the tree by $y$ window. I was glad to see them ack. In 1976 I saw not a one. Other ars this warbler had been very comon.

As we drove up from our rdwatching spree, a Western ngbird sitting on our fence flew up. hey are common in our town but he t wanted to finish the day - May 1977! Lise Perrault, Val Marie, skatchewan.

\section{DNGSPUR MEMORIES}

One of the many interesting ects of birdwatching is that one ver knows when the unexpected II happen.

t is easy to understand Atlantic rms blowing European birds to rth America, and vice versa, but at is one to make of an adult estnut-collared Longspur in full ing plumage doing on a Victoria If course on the sea front on the t day of May this year?

his brought back memories of our t birding trip to the Prairies in an ly June. My wife and I were apaching the Saskatchewan border pur car when we heard an unusual g. So we stopped and walked over pe virgin prairie, rather hilly as I nember, and found ourselves surnded by Chestnut-collared and Cown's Longspurs, Horned Larks, Buntings and meadowlarks rising falling on fluttering wings and ing all the while. The longspurs buntings were new to us, and we always remember how excited we e to see and hear all these birds their breeding grounds. Albert $R$. idson, 2144 Brighton Avenue, Vica, B.C.

\section{SQUIRREL-PROOFING BIRD BOXES}

I read with a great deal of interest G. A. Wilde's article in the Blue Jay's June issue "Squirrel Damage to Nest Boxes". We have a summer cottage at Whytewold, on Lake Winnipeg, and during the past three years we have been plagued by red squirrels chewing bird boxes and also damaging nests in trees.

This summer we decided to try an experiment. I am enclosing a diagram of the tin covering which my husband made in order to protect the hole in the bird box. We did this with our two wren houses and found that it worked very well.

Mention was made that it might be the glue in the plywood which attracts the squirrels. This might be the reason but 1 am doubtful of this. We had the wood of one of our screen windows (in storage all winter in an outhouse) chewed, and the wood was spruce (with no glue). Mrs. Jean Bancroft, 264 Campbell St., Winnipeg, Manitoba R3N 1 B5.

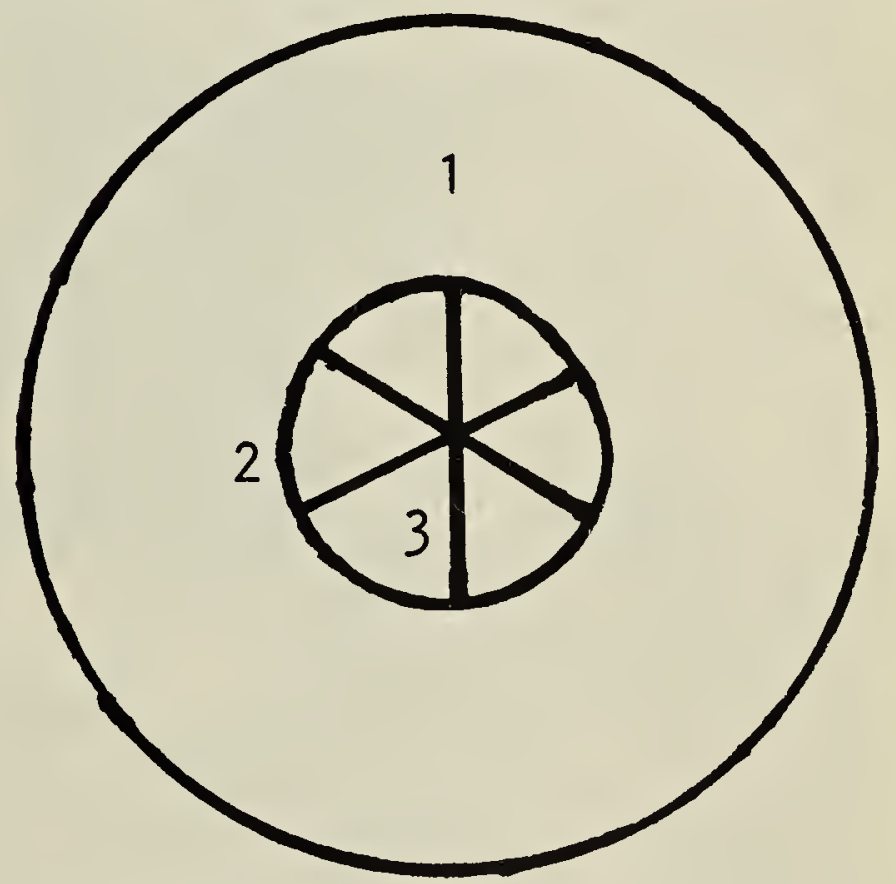

1. End of juice can $-48 \mathrm{oz}$.

2. Circle slightly in excess of entrance to bird box.

3. Tin cut into sectors from centre to circumference of circle

4. Sectors pressed back into entrance to bird box, making sure they are flush with the wood or bent back against inside of front wood panel.

5. Bird box has, therefore, an entrance faced with tin.

6. Paint same colour as box. 


\section{RABBITS AND TICKS}

When I came West with our family in 1904, there were a great many English and Scotch settlers coming in at the same time. The English settlers in particular were very pleased at being able to procure rabbit so readily, just with a bit of snare wire. Then a few years later, they had to give up eating them because the jack rabbits were so thin and covered with abcesses or blisters. Now that I know more about wood ticks, I wonder if they are not a factor in this cycle of comparative abundance and scarcity of jack rabbits. Has anyone studied the fluctuations of wood ticks in re tion to the rabbit cycles? Robertson, Indian Hea Saskatchewan.

EDITOR'S NOTE: Dr. John R. Alle professor of veterinary parasitology at University of Saskatchewan made $t$ comment on the ticks: "Most of the ti on rabbits in Saskatchewan a Haemaphysalis leporis-palustris. Lar and nymphs of woodticks Dermocen andersoni (Western Saskatchewan), variabalis (Eastern Saskatchewan) do a attach to rabbits, but would be rather $\mathrm{sm}$ and are rarely noticed by most people. 7 abscesses/blisters could possibly repres allergic reactions to the feeding ticks, bi wouldn't bet on it."

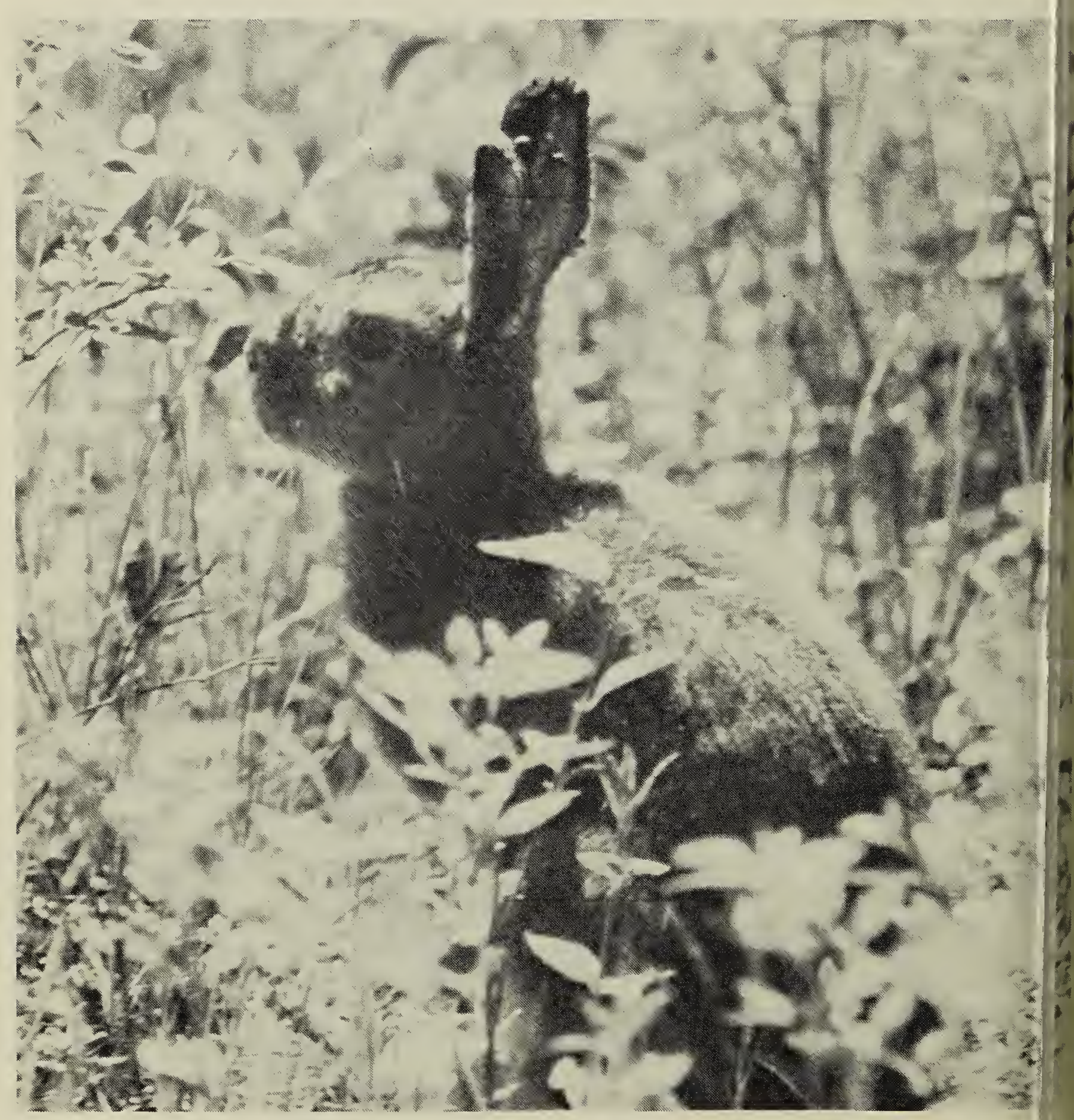

Snowshoe hare. Note ticks on ears and cheek

Gary W. b 